\title{
Translating genomic information into clinical medicine: Lung cancer as a paradigm
}

\author{
Mia A. Levy, ${ }^{1,2,3}$ Christine M. Lovly, ${ }^{2,3}$ and William Pao ${ }^{2,3,4}$ \\ ${ }^{1}$ Department of Biomedical Informatics, ${ }^{2}$ Vanderbilt-Ingram Cancer Center, ${ }^{3}$ Department of Medicine, \\ Vanderbilt University Medical School, Nashville, Tennessee 37212, USA
}

\begin{abstract}
We are currently in an era of rapidly expanding knowledge about the genetic landscape and architectural blueprints of various cancers. These discoveries have led to a new taxonomy of malignant diseases based upon clinically relevant molecular alterations in addition to histology or tissue of origin. The new molecularly based classification holds the promise of rational rather than empiric approaches for the treatment of cancer patients. However, the accelerated pace of discovery and the expanding number of targeted anti-cancer therapies present a significant challenge for healthcare practitioners to remain informed and up-to-date on how to apply cutting-edge discoveries into daily clinical practice. In this Perspective, we use lung cancer as a paradigm to discuss challenges related to translating genomic information into the clinic, and we present one approach we took at Vanderbilt-Ingram Cancer Center to address these challenges.
\end{abstract}

Knowledge about genetic alterations that drive and sustain the growth of various cancers is exploding. Using lung cancer as a model, we describe evolving trends and challenges in leveraging genetic information to inform cancer care. We briefly review the history of chemotherapy and targeted therapies in lung cancer, with a focus on the current era of therapies targeting the protein products of driver mutations occurring in single oncogenes. We discuss challenges related to how tumors will be profiled, including issues related to who should perform testing and with what platform, who should pay for testing and how gene patents may affect costs, which tumors to profile and when, and the concept of companion diagnostics. We also discuss issues related to clinical interpretations of genomic information: how will they be reported to clinicians, in what format, and using what knowledge resources (Fig. 1). Finally, we present one approach that we took at the Vanderbilt-Ingram Cancer Center to address these issues for our personalized cancer medicine initiative.

\section{Lung cancer}

Lung cancer is the leading cause of cancer-related death in the United States (Siegel et al. 2011). The overall 5-yr survival for all stages is $\sim 16 \%$. Since at least 1968 , when the international tumornode-metastasis (TNM) staging system was officially adopted as the "international language" for diagnosis and treatment of lung cancer, patients' tumors have been classified primarily according to tumor histology (International Union Against Cancer 1968). Clinically, the two main subtypes of lung cancer include small cell lung cancer (SCLC; 10\% of cases) and non-small cell lung cancer (NSCLC; $\sim 90 \%$ of cases). This Perspective will focus primarily on NSCLC, the major histologic subtype in which advances in the genomics of lung cancer have been made. NSCLC is further subdivided into adenocarcinoma, squamous cell carcinoma, and large cell carcinoma. Unfortunately, more than half of patients with NSCLC are diagnosed at advanced stages, where treatment is not curative.

\footnotetext{
${ }^{4}$ Corresponding author

E-mail william.pao@vanderbilt.edu

Article published online before print. Article and publication date are at http://www.genome.org/cgi/doi/10.1101/gr.131128.111. Freely available online
} through the Genome Research Open Access option.

\section{Treatment of lung cancer with chemotherapy}

Although lung cancer is a heterogeneous disease, the paradigm for the treatment of metastatic disease from the late 1970's to the mid2000's was largely empiric, based upon observations made in clinical trials involving cytotoxic chemotherapies. The major classes of chemotherapies include alkylating agents (e.g., cisplatin), antimetabolites (gemcitabine), microtubule inhibitors (e.g., paclitaxel), topoisomerase inhibitors (e.g., etoposide), and cytotoxic antibiotics (e.g., doxorubicin). These agents generally kill cells that divide rapidly, one of the key properties of most cancer cells. The dogma by the late 1990's was that all patients with metastatic NSCLC should receive "modern platinum-based chemotherapy doublets" (i.e., carboplatin plus an agent such as paclitaxel or gemcitabine), regardless of histology (Schiller et al. 2002). With this "one-size-fits all" approach, the therapeutic efficacy of treatment reached a plateau. A landmark trial in which $\sim 1200$ patients with advanced NSCLC were randomly assigned to one of four platinum-based chemotherapy regimens showed no significant advantage of any one regimen over the others in terms of overall survival ( $\sim 8 \mathrm{mo}$ ) (Schiller et al. 2002). The addition to platinumbased doublets of bevacizumab, a monoclonal antibody against vascular endothelial growth factor (a major regulator of angiogenesis in normal and malignant tissue), led to only a 2-mo survival benefit (12 mo versus $10 \mathrm{mo}$ ) in one study (Sandler et al. 2006) but not another (Reck et al. 2009) and was associated with an increased risk of treatment-related deaths (Sandler et al. 2006). Despite multiple efforts to identify molecular predictors of response to cytotoxic chemotherapy, none are used routinely in clinical practice (Andrews et al. 2011).

\section{Treatment of lung cancer with targeted therapies in the beginning of the genomic era: The new taxonomy of single gene driver mutations}

The first draft of the human genome was published in 2001 (Lander et al. 2001; Venter et al. 2001). Although a handful of genes (i.e., KRAS, NRAS, PTEN) were shown to be mutated in lung cancers prior to 2001, most tumor-specific gene alterations have been identified since that time (Fig. 2). With the advent of whole exome, whole genome, and whole transcriptome sequencing, the pace of discovery is accelerating. 


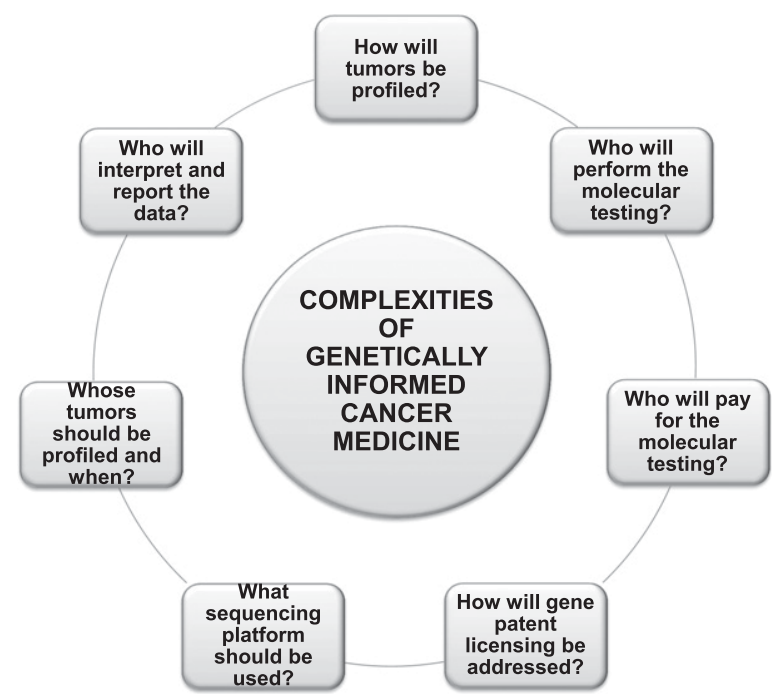

Figure 1. Complexities of genetically informed cancer medicine. As shown here, multiple factors need to be addressed in order to effectively translate knowledge of tumor gene mutations into routine clinical practice.

Genomic profiling using sequencing and other highthroughput technologies has led to an explosion of genomic classifiers for lung cancers (Chen et al. 2007; Weir et al. 2007; Shedden et al. 2008; Yu et al. 2008). Not all of these have direct clinical relevance. One of the most widely adopted classification schema in the clinic involves the use of "driver" mutations. Basic and clinical research has revealed that some genetic lesions are not only necessary for the initial development or progression of a specific tumor but are also required for the maintenance of that tumor's survival; a concept referred to as "oncogene addiction" (Weinstein 2002). Such "driver" mutations sustain tumors, but simultaneously can serve as cancer-specific targets of vulnerability to be exploited therapeutically. This notion is best exemplified by the success of imatinib (Gleevec), an ABL kinase inhibitor, in treating patients with chronic myelogenous leukemia driven and sustained by the $B C R-A B L$ oncogene (Druker et al. 2001).

Currently, most of the key "driver" mutations in NSCLC have thus far been found in genes encoding signaling proteins, such as protein kinases. By transferring phosphate groups from ATP to specific target proteins, these signaling proteins are critical regulators of cellular proliferation and survival. "Driver" mutations are also found in GTPases, which are intracellular enzymes that typically function downstream from protein kinases to propagate cell growth, proliferation, and survival signals.

In lung cancer, the main genes with known or potential "driver" mutation status currently include EGFR (10\%-30\%), KRAS (15\%-30\%), FGFR1 (20\%), ERBB2 (also known as HER2) (2\%-5\%), PIK3CA (2\%-5\%), ALK (3\%-5\%), BRAF (1\%-3\%), ROS1 (1\%), MAP2K1 (also known as MEK1) (1\%), RET (1\%), NRAS (1\%), and AKT1
$(<1 \%)$ (Table 1). For details on the types of recurrent genetic alterations that affect these genes in lung cancer, see Pao and Chmielecki (2010), Weiss et al. (2010), Pao et al. (2011), Bergethon et al. (2012), Lovly and Pao (2012), and Pao and Hutchinson (2012). Importantly, a tumor with a mutation in one of these genes usually does not have a mutation in another gene (except for PIK3CA). This finding implies that these mutations define clinically distinct entities.

A major reason why this classification scheme has been adopted clinically is that specific "driver" mutations are linked with sensitivity and/or resistance to existing or emerging targeted therapies. Such therapies are different from conventional cytotoxic chemotherapies in that they "target" a mutant protein specific to tumors, not found in normal cells. Thus, the therapeutic window of drug efficacy can potentially be greater with fewer of the side effects seen with cytotoxic chemotherapy.

The first successful example of a targeted therapy based upon driver mutations in lung cancer involves the epidermal growth factor receptor (EGFR). EGFR is a receptor tyrosine kinase that normally regulates intracellular signaling pathways to promote cell growth and proliferation. Lung tumors harboring specific activating mutations in the EGFR kinase domain are exquisitely sensitive to the EGFR tyrosine kinase inhibitors (TKIs), erlotinib (Tarceva), and gefitinib (Iressa). More than $70 \%$ of patients with EGFR mutant tumors will display a radiographic response to EGFR TKIs, while response rates to traditional platinum-based chemotherapy regimens are $\sim 30 \%$ (Mitsudomi et al. 2009; Maemondo et al. 2010). Only $1 \%$ of EGFR wild-type (i.e., non-EGFR mutant) tumors will respond to EGFR TKI therapy (Mok et al. 2009). The latter "wild-type" category includes tumors with other genetic alterations, such as KRAS mutations, $A L K$ fusions, ROS1 fusions, etc. Unfortunately, even though patients treated with EGFR TKIs are still not cured of lung cancer, progression-free survival and quality of life are improved with this targeted therapy versus traditional chemotherapy (Mok et al. 2009).

The list of such examples of targetable oncogenic driver mutations continues to grow. Patients with lung tumors that are refractory to standard chemotherapy but that harbor specific $A L K$ gene fusions display response rates of $\sim 60 \%$ to the ALK tyrosine

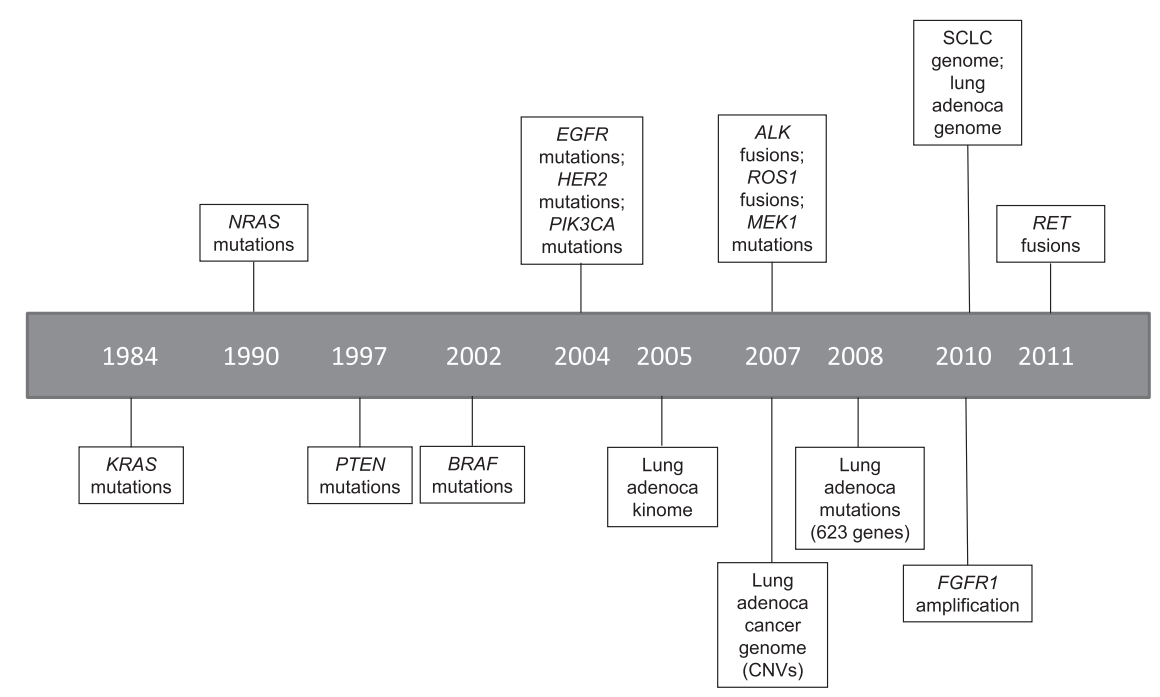

Figure 2. Timeline for the discovery of significant molecular alterations in lung cancer. (Adenoca) adenocarcinoma; (CNVs) copy number variants; (SCLC) small cell lung cancer. 
Table 1. Molecular subsets of NSCLC defined by "driver" mutations

\begin{tabular}{|c|c|c|}
\hline Gene & Frequency & References \\
\hline AKT1 & $\leq 1 \%$ & $\begin{array}{l}\text { Bleeker et al. } 2008 \\
\text { Do et al. } 2008 \\
\text { Malanga et al. } 2008\end{array}$ \\
\hline$A L K$ & $3 \%-7 \%$ & $\begin{array}{l}\text { Soda et al. } 2007 \\
\text { Koivunen et al. } 2008 \\
\text { Kwak et al. } 2010\end{array}$ \\
\hline$B R A F$ & $1 \%-3 \%$ & $\begin{array}{l}\text { Pratilas et al. } 2008 \\
\text { Lee et al. } 2010 \\
\text { Paik et al. } 2011\end{array}$ \\
\hline EGFR & $10 \%-30 \%$ & $\begin{array}{l}\text { Lynch et al. } 2004 \\
\text { Paez et al. } 2004 \\
\text { Pao et al. } 2004\end{array}$ \\
\hline FGFR1 & $20 \%$ & $\begin{array}{l}\text { Weiss et al. } 2010 \\
\text { Dutt et al. } 2011\end{array}$ \\
\hline HER 2 & $2 \%-5 \%$ & $\begin{array}{l}\text { Sonobe et al. } 2006 \\
\text { Lee et al. } 2010\end{array}$ \\
\hline KRAS & $15 \%-30 \%$ & $\begin{array}{l}\text { Tsao et al. } 2006 \\
\text { Riely et al. } 2008\end{array}$ \\
\hline MEK1 & $1 \%$ & Marks et al. 2008 \\
\hline NRAS & $1 \%$ & $\begin{array}{l}\text { Brose et al. } 2002 \\
\text { Ding et al. } 2008\end{array}$ \\
\hline PIK3CA & $1 \%-3 \%$ & $\begin{array}{l}\text { Kawano et al. } 2006 \\
\text { Lee et al. } 2010\end{array}$ \\
\hline RET & $1 \%$ & $\begin{array}{l}\text { Kohno et al. } 2012 \\
\text { Takeuchi et al. } 2012 \\
\text { Lipson et al. } 2012 \\
\text { Ju et al. } 2012\end{array}$ \\
\hline ROS1 & $1 \%$ & Bergethon et al. 2012 \\
\hline
\end{tabular}

kinase inhibitor, crizotinib (Kwak et al. 2010). In contrast, typical response rates in the setting of pretreated lung cancer are typically around 10\% (Hanna et al. 2004). Patients with $A L K$ fusion-positive lung cancer do not respond to treatment with EGFR TKIs (Shaw et al. 2009). Similarly, ROS1 fusion-positive tumors are also highly sensitive to crizotinib (touted as an ALK TKI, but with activity also against ROS1 and MET) (Bergethon et al. 2012). In addition, ERBB2 (HER2) mutant tumors are responsive to HER2 TKIs (De Greve et al. 2012), and $B R A F$ mutant tumors may be responsive to the mutantspecific BRAF inhibitor, vemurafenib (Gautschi et al. 2012).

As a result of these compelling data, multiplex mutational profiling of lung tumors is now part of accepted standard clinical and pathology practice at locations throughout the US (Pao et al. 2009; Dias-Santagata et al. 2010; Sequist et al. 2011; Su et al. 2011). Such "first-generation" profiling of about 10 genes implicated in lung-cancer pathogenesis will detect mutations in roughly half of unselected NSCLCs and nearly $90 \%$ of lung adenocarcinomas from East Asian never smokers (Sun et al. 2010; Li et al. 2011).

\section{Maximizing the potential of genetically informed cancer medicine}

The explosion of genomic information offers great promise toward an era of "precision" or genetically informed cancer medicine, where patients are treated rationally according to the genetic makeup of their individual tumors rather than empirically based upon histology. We are just at the beginning of this paradigm shift, especially because translation of basic scientific findings to the clinic often takes time and education for all involved. In addition, the knowledge explosion presents many challenges (Fig. 1). Below we discuss many of the issues that remain to be addressed and our preliminary experience at the Vanderbilt-Ingram Cancer Center in solving them.

\section{How will tumors be profiled?}

DNA sequencing technology is undergoing a revolution, and advances in massively parallel technologies have dramatically reduced the cost of sequencing (Macconaill and Garraway 2010). These developments imply that comprehensive tumor genome profiling will not only occur as part of pilot programs (Roychowdhury et al. 2011) but will also become widely adopted in the future. To be clinically applicable, such profiling should be performed in the appropriate settings, i.e., in laboratories that are compliant with the Clinical Laboratory Improvement Amendment (CLIA) of 1988 administered by the Center for Medicare Services (CMS) and in accord with guidelines set forth by the College of American Pathologists (CAP) (for details, see Febbo et al. 2011). Presumably, most assays will be performed using formalin-fixed paraffin-embedded tissues and not fresh frozen tissues, since in the vast majority of patients with metastatic disease, only the former is available.

\section{Who will perform the testing, local hospitals or reference laboratories?}

Some local and many academic hospitals are able to perform a limited number of molecular and cytogenetic tests on a select number of cancer genes using technologies that have been widely available in CLIA labs for many years. However, the technology platforms for high throughput tumor gene mutation testing are changing every year. How will molecular diagnostics laboratories keep up with the cost of replacing their technology and validating the new assays every few years? Can each local hospital afford to develop/perform such assays on its own, or will such assays need to be outsourced because of their inherent complexity? Until the "landscape" is settled, reference laboratories and only a handful of well-endowed institutions are likely to be able to offer comprehensive tumor profiling for patients. Perhaps even more importantly, there are a limited number of trained molecular pathologists worldwide who can run such labs. The training of future pathologists will need to change to accommodate the rise in demand for molecular testing.

\section{Who will pay for the molecular testing?}

The cost of current molecular diagnostic assays can vary from hundreds of dollars (for single gene sequencing) to thousands of dollars (for multigene profiling or fluorescent in situ hybridization). The costs of such tests are reimbursable by insurers, but at some point, as the " $\$ 1000$ genome" becomes a reality (Macconaill and Garraway 2010), the cost of comprehensive tumor profiling will actually be cheaper and more practical than individual gene tests. When that time comes, it will be more cost effective on a societal level for patients diagnosed with cancer to undergo routine comprehensive tumor profiling at various stages of treatment, provided that the use of expensive therapies is restricted to only those most likely to benefit.

\section{How will gene patent licensing be addressed?}

In 2005 , it was estimated that nearly $20 \%$ of human genes were explicitly claimed as U.S. intellectual property (Jensen and Murray 2005). Many important cancer genes are covered by patents, so not everyone can legally analyze them for commercial purposes without proper licenses (Kean 2011). In fact, investigating all of the relevant patent claims (issued and pending) for possible infringement on the testing of about 100 cancer genes was estimated in 
2011 to cost at least $\$ 35$ million (Kean 2011). Creative solutions among all stakeholders, including lawyers, businesspeople, and policymakers, will need to be made to pave the way forward. Fortunately, recent arguments have been made that perhaps these claims have been overstated and there appears to be little evidence that would support an assumption that gene patents pose a substantial impediment to technologies like whole-genome sequencing (Holman 2012).

\section{What sequencing platform should be used?}

How much average gene depth and coverage are appropriate for profiling? Is variable coverage across key genes acceptable? Does the whole exome need to be done, the whole genome, or the whole transcriptome? Or should just "cancer genes" be examined? Importantly, can the test and the interpretation be performed in a clinically relevant timeframe, i.e., within 1 to $2 \mathrm{wk}$ of the first clinic visit, so that patients with metastatic disease can start treatment as soon as possible? One current "second-generation" approach involves targeted capture and resequencing of about 200 genes implicated in cancer with high coverage (Lipson et al. 2012). This particular platform is attractive because it detects all known genomic alterations that could have relevance, i.e., point mutations, insertions, deletions, rearrangements, and copy-number alterations. Moreover, the assay is performed in a CLIA-certified laboratory with a quick turnaround time.

\section{What about companion diagnostics?}

According to the US Food and Drug Administration, a companion diagnostic device is an in vitro diagnostic (IVD) device that provides information that is essential for the safe and effective use of a corresponding therapeutic product. Examples include an $A L K$ fluorescence in situ hybridization (FISH) test to detect ALK gene rearrangements for the use of crizotinib in lung cancer and an allele-specific PCR-based test to detect $B R A F^{V 600 E}$ mutations for the use of vemurafanib (a BRAF inhibitor) in melanoma. Currently, when an appropriate scientific rationale supports such an approach, the FDA encourages the development of therapeutic products that depend on the use of approved or cleared IVD companion diagnostic devices. However, how is the use of companion diagnostics compatible with multiplex mutational profiling? If 100 different mutations are found that have implications for therapy, will the FDA mandate use of 100 different diagnostic devices, each of which could cost thousands of dollars? How is that feasible from a practical standpoint, both from a tissue availability perspective and from a financial perspective? The FDA and/or other regulatory agencies will need to reconsider this approach as reliable genome-wide sequencing platforms become available.

\section{Whose tumors should be profiled and when?}

At a minimum, tumors with a high prevalence of potentially actionable mutations, such as NSCLCs, should be tested today. Ideally, to be clinically useful, patients' tumors should be profiled at the time of diagnosis, allowing for treatment prioritization. However, recent data demonstrates that tumors undergo evolution over time, acquiring resistance with new mutations and genomic alterations (Lovly and Pao 2012). While it is common practice to reassess the molecular status of liquid tumors, invasive biopsy techniques make this less practical in solid tumors. Moreover, metastatic lesions within patients can be heterogeneous, with one site of metastasis harboring a given drug resistance mechanism and another site harboring a different mechanism (Engelman et al. 2007). These observations raise the question as to whether patients should have more than one tumor examined at any given time. Feasibility in most instances will limit whether or not this practice occurs (e.g., can multiple sites be biopsied safely?). Another question is whether patients should undergo repeat tumor profiling after each treatment course to assist in prioritizing additional/ future therapies. Cost-benefit ratios will likely guide this practice.

\section{How will clinicians be assisted in interpreting the results in order to make actionable decisions for patient care?}

Information regarding the therapeutic implications of tumor gene mutation testing results is clinically complex. Mutations in the same gene may confer primary sensitivity, primary resistance, or secondary resistance to the same drug (Pao and Chmielecki 2010). For instance, in lung adenocarcinoma, mutations in EGFR exon 19 deletions and exon 21 point mutations (L858R) confer primary sensitivity to EGFR TKI's (Lynch et al. 2004; Paez et al. 2004; Pao et al. 2004), whereas EGFR exon 20 mutations (T790M) confer primary or secondary resistance to the same drugs (Kobayashi et al. 2005; Pao et al. 2005a). Tumors harboring mutations in KRAS (Pao et al. 2005b; Riely et al. 2009) or $A L K$ (Shaw et al. 2009) are usually unresponsive to EGFR TKIs.

Tumors may harbor alterations that affect not only DNA but also RNA or protein, each of which may have different therapeutic implications. For example, in lung cancer, EGFR DNA mutations predict for high sensitivity to EGFR tyrosine kinase inhibitors, while EGFR DNA copy-number levels, mRNA expression levels, or protein levels have little or no predictive value. Providers in a busy medical practice will be challenged to keep up with all of this multifactorial and clinically significant detail.

\section{Who will interpret and report genomic results to physicians?}

Traditionally, molecular diagnostic laboratories generate an interpretive report regarding basic information on the test performance and clinical significance of the results. Even with only a few gene mutations tested in the clinical lab today, busy laboratory directors may not have sufficient time to stay current with the latest knowledge. This challenge will continue to grow as molecular testing techniques scale to include full sequencing of hundreds or thousands of genes for clinical use. Generally, there is a lack of publically accessible knowledge resources available to assist both molecular diagnostic labs and practicing clinicians in interpreting the clinical significance of these results.

\section{What will be reported?}

It is currently accepted that knowledge of tumor driver mutation status is clinically helpful, allowing for the prioritization of targeted therapy treatment. However, should clinicians and patients also know about the status of other mutations, such as passenger mutations that are currently not thought to be biologically and clinically relevant? What about mutations with prognostic significance? Or mutations of unknown significance?

A molecular diagnostic test can have analytic validity, clinical validity, and clinical utility (Febbo et al. 2011). Briefly, analytic validity attests to the reproducibility and quality of the test. Clinical validity implies that the marker identifies two groups that can be distinguished biologically and have different outcomes, but this 
observation may not indicate that it should be used for routine clinical care. Clinical utility implies that high-level evidence shows that use of the marker improves patient outcome sufficiently to justify its incorporation into routine clinical care. As mutations are uncovered, we will eventually know all of the ones associated with clinical utility, i.e., that can help prioritize therapy. Until that time, however, we will need to be flexible and inclusive, but cognizant that most of the mutations identified will be of unknown significance. One approach that many places are adopting involves the reporting of clinically actionable mutations, with statements regarding (1) whether a mutation has been linked to an FDAapproved drug within the specific disease being tested, (2) whether a mutation has been linked to an FDA-approved drug within a different disease from that being tested (since effective targeted treatment in one disease does not always translate to another), (3) whether a mutation has been linked to a non-FDA approved drug in preclinical models or early phase clinical trials, and (4) whether a mutation has not been linked to any drug.

\section{How will tumor mutation results be reported?}

Current methods for reporting tumor gene mutation testing results for clinical use have several limitations with respect to report content and format. Today, most molecular diagnostics laboratories perform tumor gene mutation testing on one or two genes at a time, and only test for the few most common mutations within that gene. The report content consists of a full-page text description of each gene tested. The report contains static information regarding the testing technique and the clinical significance of the gene mutation detected with respect to drug therapies for a particular disease (i.e., "tumors with EGFR exon 19 deletion are sensitive to EGFR TKI's in non-small cell lung cancer").

While reports typically contain one or two references to support these types of high-level statements regarding drug sensitivity, they may not have the most up-to-date information. The references are essential to clinicians in that they provide important information regarding the appropriate clinical context for use of these drugs (e.g., in the metastatic or adjuvant setting). This level of detail assists the treating physician in making actionable treatment decisions taking into account the tumor gene mutation results. Even when the information is most current, it is only relevant for that moment in time when the report is created. Six months later, when the patient's tumor has progressed and a new treatment is considered, the interpretation in the original report may no longer be up-to-date given the pace at which new knowledge in this area is emerging. How will providers and patients remain updated regarding changes in the interpretation of results as new evidence emerges?

In addition, these reports lack information regarding tumor/ gene mutation-directed clinical trials, one of the main actionable treatment decisions that can result from this type of molecular testing today. However, clinical trial availability changes even more rapidly than the clinical evidence. Even when open clinical trials are included in the interpretive report at the time it is generated, how will providers and patients become notified when new trials are available that may be relevant to the patient's care?

Furthermore, the current approach of reporting the significance of one gene at a time does not address the need to account for how multiple genes affect the sensitivity of a particular drug or drug regimen. This is in part due to the gene-oriented view of most reports as opposed to a drug-oriented view where the results of multiple genes can be taken into account simultaneously. This is a difficult challenge to solve given the current level of clinical evidence; however, it will become more and more important as new targets and new therapies emerge.

There are also several limitations with respect to the format of the reports themselves. Free-text reports are typically scanned into the electronic health record (EHR) or transmitted via HL7 messaging from the laboratory information system as text documents. Free-text reports and image files are not computable with respect to enabling downstream clinical decision support for treating physicians. However, there are a limited number of laboratory information systems that have adequate structured representation of genetic testing results. Organizations such as HL7 are working in conjunction with molecular diagnostic and testing societies to develop an information model to adequately represent genetic testing results. However, the challenges with respect to nextgeneration sequencing technologies are great in this regard.

Finally, the interpretive reports are static documents that are only relevant at a moment in time, a requirement for medical-legal purposes. While the results of the mutation testing for a given date will not change (e.g., EGFR T790M mutation detected on specimen from January 15,2011$)$, the interpretation of the clinical significance of the results will change over time. Thus, an opportunity exists to separate the static from the dynamic components of molecular diagnostic reports. The current approach of one report for one gene does not scale when comprehensively reporting the results for multiple genes and mutations. Thus, multiparameter data visualization and presentation represent another significant challenge.

\section{How will tumor mutation results be used in clinical decision support systems (CDSSs)?}

Beyond the traditional approach of providing decision support through interpretive reports, opportunities exist to utilize tumor gene mutation testing results directly in clinical decision support systems for cancer treatment plan selection. CDSSs have recently been developed to support pathway and guideline compliance (Neubauer et al. 2010). These tools may be standalone applications or integrated directly into electronic health records. They provide recommendations for treatment selection based on multiple tumor and patient features. Clinical practice guidelines for ASCO and the National Cancer Comprehensive Network (NCCN) already recommend EGFR testing in lung cancer as standard of care, but they provide little support for variant level interpretation of results to guide treatment. It is anticipated that CDSSs will utilize these new tumor features in their recommendations for treatment prioritization, but exactly how remains to be seen.

\section{How will knowledge bases that catalog the associations between mutations and clinical outcomes be maintained and funded?}

From the above discussion, it is clear that knowledge bases are needed to support clinicians, molecular pathologists, and patients in understanding the evolving clinical significance of tumor gene mutations. Who will fund these knowledge bases and who will maintain them? With some mutations occurring at a frequency of $<1 \%$, clinical trials cannot be expected to answer every question regarding the significance of rare mutations. Similarly, observational cohort studies and case reports in the literature can provide a starting point for knowledge extraction, but also will not provide sufficient power to account for rare mutations and multiple simultaneous mutations. Large databases of patient level cases from 
multiple institutions will be needed to aggregate knowledge sufficient for discovery and interpretation of clinical significance. We have started one such database for EGFR mutations in lung cancer (Horn et al. 2011).

\section{Implementation of genome directed cancer treatment at Vanderbilt}

The Vanderbilt-Ingram Cancer Center was faced with the challenges discussed above when we implemented "first-generation" (SNaPshot-based) tumor gene mutation testing for NSCLC in our CLIA-certified molecular diagnostics lab in July 2010 (Su et al. 2011). Initially, we needed to determine which tumors to test and when. We chose NSCLC and melanoma because they had actionable mutations as part of standard of care and active clinical trials. Tumors are tested at diagnosis and at time of rebiopsy after disease recurrence or progression. We took a practical and economic approach to selection of the molecular diagnostic testing platform in choosing to use an ABI SNaPshot platform that was already in use in our CLIA certified diagnostic lab. Given that a limited number of mutations could be tested simultaneously using this platform $(\sim 40)$, we chose to create disease-specific testing panels for lung cancer and melanoma. We selected variants to test that were prevalent in at least $1 \%$ of tumors in each respective disease. This helped maximize the likelihood of a mutation being detected using this assay.

Faced with reporting over 40 different mutations in nine genes for lung cancer, we needed an alternate solution to the traditional one-gene one-report approach to reporting. To address the above issues, we made the key decision to decouple reporting of the tumor gene mutation testing results from the interpretation of their clinical significance. Tumor gene mutation results are now reported as discrete data elements in the laboratory information system. Each gene mutation in the panel is coded and reported as "Detected" or "Not Detected" which makes this information computable. The results are then transmitted to the electronic health record and visualized in multiple ways that aggregate and abstract the results to enable rapid review of a large amount of information (Fig. 3). Finally, individual results are linked to a knowledge base called "My Cancer Genome" that provides information on the clinical significance of specific gene mutations for a particular disease including information on gene-associated clinical trials open at Vanderbilt and worldwide. The information in My Cancer Genome is continuously updated, creating a dynamic interpretation for clinicians who may review the results several months later as the patient's state changes. This combination of reporting static testing results as discrete data, abstract data visualization, and links to dynamic knowledge services has provided an initial scalable solution at our institution. In addition to being integrated into Vanderbilt's EHR, My Cancer Genome is freely available online (www.mycancergenome.org) for public use.

\section{Conclusion and future directions}

Antimicrobial testing today is taken for granted as a routine part of medicine, but history suggests that it actually took a long time to become standardized. In 1928, Alexander Fleming discovered
A.

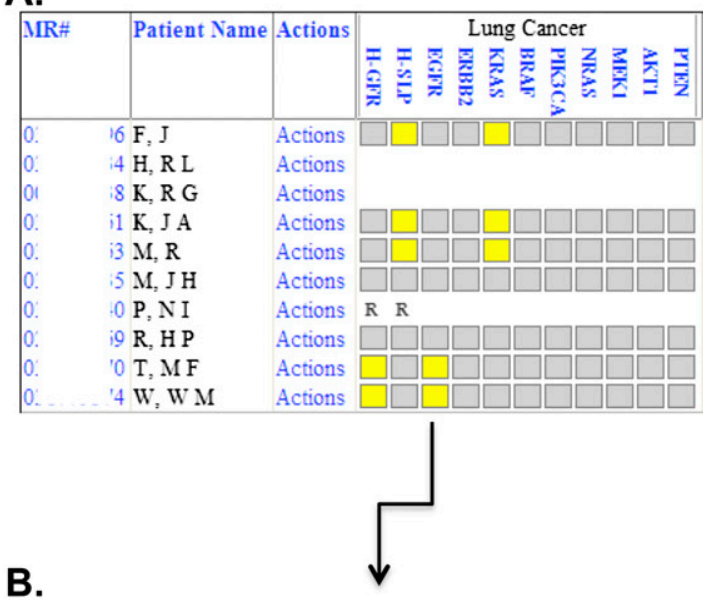

C.
What is EGFR?
EGFR in Lung Cancer
EGFR exon 19 deletion
Clinical Trials

\section{EGFR Exon 19Deletion in Non-Small Cell Lung Cancer}

\begin{tabular}{|c|c|}
\hline \multicolumn{2}{|l|}{ Properties } \\
\hline Location of mutation & Kinase domain (exon 19) \\
\hline Frequency of EGFR mutation & $\begin{array}{l}-10 \% \text { of all NSCLC in the USA } \\
-35 \% \text { of all NSCLC in Asia }\end{array}$ \\
\hline Frequency of EGFR exon 19 deletion mutation & $48 \%$ of EGFR mutant tumors \\
\hline \multicolumn{2}{|l|}{ Implications for Targeted Therapeutics } \\
\hline Response to EGFR TKls & Confers increased sensitivity \\
\hline Response to anti-EGFR antibodies & Currently no role for EGFR mutation in predicting response \\
\hline
\end{tabular}

EGFR exon 19 deletions are in-frame deletions occurring within exon 19, which encodes part of the kinase domain. This mutation occurs with a frequency of approximately 48\% in EGFR mutant lung tumors (Mitsudomi and Yatabe 2010). In the metastatic setting. EGFR mutations are strong predictors of efficacy for the EGFR tyrosine kinase inhibitors (TKIs), erlotinib (Tarceva) and gefitinib (Iressa). Patients whose tumors harbor EGFR exon 19 deletions display a >50$70 \%$ radiographic response rate in prospective trials, including randomized phase III trials (Fukuoka et al. 2011: Maemondo et al. 2010; Mitsudomi and Yatabe 2010; Mok et al. 2009: Rosell et al. 2009: Rosell et al. 2011: Zhou et al. 2011). Compared to those with EGFR wild type tumors, patients with EGFR mutant tumors display a longer progression-free survival on EGFR TKI therapy than those who receive chemotherapy. Patients with metastatic EGFR mutant tumors treated with 'first-generation' EGFR TKIs have a median survival of approximately two years (Fukuoka et al. 2011: Maemondo et al. 2010; Mitsudomi and Yatabe 2010; Mok et al. 2009; Rosell et al. 2009; Rosell et al. 2011). Prolonged survival may also be due to the fact that patients with EGFR mutant tumors have a better prognosis in general compared to those with EGFR wild type tumors (Kosaka et al. 2009: Marks et al. 2008). Patients with EGFR mutant tumors treated with an EGFR TKI in the first-line setting may live longer than those treated in the second-line setting ( 30.5 months vs. 23.6 months, $p=0.31$ ) (Maemondo et al. 2010 ).

\section{EGFR EXON 20 INSERTION Not Detected}

Figure 3. Screenshot visualizing tumor gene mutation results in the electronic health record linked to decision support. $(A)$ In the provider dashboard, patients are listed in separate rows with their respective gene mutation results shown as colored indicators in each column (yellow: mutation detected; gray: mutation not detected). "H-GFR" and "H-SLP" refer to the specific diagnostic tests performed, as named by the molecular diagnostic lab, while the remaining nine columns refer to the specific genes assessed for mutations. The user clicks on a specific gene indicator to view the specific gene mutation results shown in $B$. Gene mutations are reported using the REFSEQ nomenclature with results reported as Detected or Not Detected. The user clicks on the specific gene mutation and is taken to C. Summary of the clinical significance for the specific gene mutation in the patient's specific cancer diagnosis.

\section{Genome Research www.genome.org}


penicillin, marking the start of modern antibiotics. In the same decade, he made a contribution to modern antibiotic susceptibility testing by developing a forerunner of contemporary minimum inhibitory concentration methodology. Diffusion methods of antibiotic susceptibility testing were developed further in the ensuing decades, but it was not until 1975, when a specific method (the Kirby-Bauer disc diffusion technique) became the basis for a routine standardized national method accredited by the National Committee for Laboratory Standards (Wheat 2001). Such antibiotic susceptibility testing reports are the staple of medicine today, allowing physicians to make rational and effective choices regarding the use of antibiotics to treat infections arising from diverse origins (e.g., gram-positive cocci, gram-negative rods, etc.)

Analogously, decades of research designed to elucidate the genetic basis of cancers have now revealed multiple clinically relevant molecular subsets of disease. These discoveries are leading to a new taxonomy of cancer, which holds the promise of rational rather than empiric approaches for treatment. Lung cancer currently represents one of the best paradigms for this new shift. Tumors can now already be tested for multiple different "driver" mutations at a time, helping to prioritize the use of targeted therapies most likely to benefit individual patients. However, we are just at the beginning of this new paradigm. Great efforts still need to be made to overcome the many challenges currently facing the field. When comprehensive mutational profiling becomes efficient, cost-effective, and easily interpretable by practicing clinicians, we are confident that just like antibiotic susceptibility testing, it will become a part of routine cancer care.

\section{Competing interest statement}

William Pao reports consulting for MolecularMD, AstraZeneca, Bristol-Myers Squibb, Symphony Evolution, and Clovis Oncology. His lab has received research funding from Enzon, Xcovery, AstraZeneca, and Symphogen. Rights to EGFR T790M testing were licensed on his behalf and others to MolecularMD by MSKCC. The other authors have no conflicts to disclose.

\section{Acknowledgments}

We acknowledge support from the VICC Specialized Program of Research Excellence in Lung Cancer grant (CA90949), the VanderbiltIngram Cancer Center Core grant (CA68485), the V Foundation, the TJ Martell Foundation, the Robert J. Kleberg Jr. and Helen C. Kleberg Foundation, and an anonymous donor. We thank John Iafrate and Dora Dias-Santagata at MGH for assistance with establishing the lung and melanoma SNaPshot assays. This work would not have been possible without contributions from the entire Personalized Cancer Medicine Initiative and My Cancer Genome teams at Vanderbilt.

Author contributions: M.A.L., C.M.L., and W.P. conceived, wrote, and approved the manuscript.

\section{References}

Andrews J, Yeh P, Pao W, Horn L. 2011. Molecular predictors of response to chemotherapy in non-small cell lung cancer. Cancer J 17: 104-113.

Bergethon K, Shaw AT, Ignatius Ou SH, Katayama R, Lovly CM, McDonald NT, Massion PP, Siwak-Tapp C, Gonzalez A, Fang R, et al. 2012. ROS1 rearrangements define a unique molecular class of lung cancers. J Clin Oncol 30: 863-870.

Bleeker FE, Felicioni L, Buttitta F, Lamba S, Cardone L, Rodolfo M, Scarpa A, Leenstra S, Frattini M, Barbareschi M, et al. 2008. AKT1 ${ }^{E 17 K}$ in human solid tumours. Oncogene 27: 5648-5650.
Brose MS, Volpe P, Feldman M, Kumar M, Rishi I, Gerrero R, Einhorn E, Herlyn M, Minna J, Nicholson A, et al. 2002. BRAF and RAS mutations in human lung cancer and melanoma. Cancer Res 62: 6997-7000.

Chen HY, Yu SL, Chen CH, Chang GC, Chen CY, Yuan A, Cheng CL, Wang $\mathrm{CH}$, Terng HJ, Kao SF, et al. 2007. A five-gene signature and clinical outcome in non-small-cell lung cancer. N Engl J Med 356: 11-20.

De Greve J, Teugels E, Geers C, Decoster L, Galdermans D, De Mey J, Everaert H, Umelo I, Veld PI, Schallier D. 2012. Clinical activity of afatinib (BIBW 2992) in patients with lung adenocarcinoma with mutations in the kinase domain of HER2/neu. Lung Cancer 76: 123-127.

Dias-Santagata D, Akhavanfard S, David SS, Vernovsky K, Kuhlmann G, Boisvert SL, Stubbs H, McDermott U, Settleman J, Kwak EL, et al. 2010. Rapid targeted mutational analysis of human tumours: A clinical platform to guide personalized cancer medicine. EMBO Mol Med 2: 146-158.

Ding L, Getz G, Wheeler DA, Mardis ER, McLellan MD, Cibulskis K, Sougnez C, Greulich H, Muzny DM, Morgan MB, et al. 2008. Somatic mutations affect key pathways in lung adenocarcinoma. Nature 455: 1069-1075.

Do H, Solomon B, Mitchell PL, Fox SB, Dobrovic A. 2008. Detection of the transforming $A K T 1$ mutation E17K in non-small cell lung cancer by high resolution melting. BMC Res Notes 1: 14. doi: 10.1186/1756-0500$1-14$

Druker BJ, Talpaz M, Resta DJ, Peng B, Buchdunger E, Ford JM, Lydon NB, Kantarjian H, Capdeville R, Ohno-Jones S, et al. 2001. Efficacy and safety of a specific inhibitor of the BCR-ABL tyrosine kinase in chronic myeloid leukemia. N Engl J Med 344: 1031-1037.

Dutt A, Ramos AH, Hammerman PS, Mermel C, Cho J, Sharifnia T, Chande A, Tanaka KE, Stransky N, Greulich H, et al. 2011. Inhibitor-sensitive FGFR1 amplification in human non-small cell lung cancer. PloS One 6: e20351. doi: 10.1371/journal.pone.0020351.

Engelman JA, Zejnullahu K, Mitsudomi T, Song Y, Hyland C, Park JO, Lindeman N, Gale CM, Zhao X, Christensen J, et al. 2007. MET amplification leads to gefitinib resistance in lung cancer by activating ERBB3 signaling. Science 316: 1039-1043.

Febbo PG, Ladanyi M, Aldape KD, De Marzo AM, Hammond ME, Hayes DF, Iafrate AJ, Kelley RK, Marcucci G, Ogino S et al. 2011. NCCN Task Force report: Evaluating the clinical utility of tumor markers in oncology. $J$ Natl Compr Canc Netw 9: S1-S32.

Gautschi O, Pauli C, Strobel K, Hirschmann A, Printzen G, Aebi S, Diebold J. 2012. A patient with BRAF V600E lung adenocarcinoma responding to vemurafenib. J Thorac Oncol doi: 10.1097/JTO.0b0.13e318262903.

Hanna N, Shepherd FA, Fossella FV, Pereira JR, De Marinis F, von Pawel J, Gatzemeier U, Tsao TC, Pless M, Muller T, et al. 2004. Randomized phase III trial of pemetrexed versus docetaxel in patients with non-small-cell lung cancer previously treated with chemotherapy. J Clin Oncol 22: 1589-1597.

Holman CM. 2012. Debunking the myth that whole-genome sequencing infringes thousands of gene patents. Nat Biotechnol 30: 240-244.

Horn L, Chen H, Lovly CM, Andrews J, Yeh P, Levy MA, Pao W. 2011. DIRECT: DNA-mutation Inventory to Refine and Enhance Cancer Treatment-A catalogue of clinically relevant somatic mutations in lung cancer. In J Clin Oncol 29, Supplement, abstract no. 7575. 2011 ASCO Annual Meeting, Chicago, Illinois.

International Union Against Cancer (UICC). 1968. TNM classification of malignant tumours. Geneva, Switzerland.

Jensen K, Murray F. 2005. Intellectual property landscape of the human genome. Science 310: 239-240.

Ju YS, Lee WC, Shin JY, Lee S, Bleazard T, Won JK, Kim YT, Kim JI, Kang JH, Seo JS. 2012. A transforming KIF5B and RET gene fusion in lung adenocarcinoma revealed from whole-genome and transcriptome sequencing. Genome Res 22: 436-445.

Kawano O, Sasaki H, Endo K, Suzuki E, Haneda H, Yukiue H, Kobayashi Y, Yano M, Fujii Y. 2006. PIK3CA mutation status in Japanese lung cancer patients. Lung Cancer 54: 209-215.

Kean S. 2011. Human genome 10th anniversary. The Human Genome (patent) Project. Science 331: 530-531.

Kobayashi S, Boggon TJ, Dayaram T, Janne PA, Kocher O, Meyerson M, Johnson BE, Eck MJ, Tenen DG, Halmos B. 2005. EGFR mutation and resistance of non-small-cell lung cancer to gefitinib. N Engl J Med 352: 786-792.

Kohno T, Ichikawa H, Totoki Y, Yasuda K, Hiramoto M, Nammo T, Sakamoto H, Tsuta K, Furuta K, Shimada Y, et al. 2012. KIF5B-RET fusions in lung adenocarcinoma. Nat Med 18: 375-377.

Koivunen JP, Mermel C, Zejnullahu K, Murphy C, Lifshits E, Holmes AJ, Choi HG, Kim J, Chiang D, Thomas R, et al. 2008. EML4-ALK fusion gene and efficacy of an ALK kinase inhibitor in lung cancer. Clin Cancer Res 14: 4275-4283.

Kwak EL, Bang YJ, Camidge DR, Shaw AT, Solomon B, Maki RG, Ou SH, Dezube BJ, Janne PA, Costa DB, et al. 2010. Anaplastic lymphoma kinase inhibition in non-small-cell lung cancer. N Engl J Med 363: 1693-1703. 
Lander ES, Linton LM, Birren B, Nusbaum C, Zody MC, Baldwin J, Devon K, Dewar K, Doyle M, FitzHugh W, et al. 2001. Initial sequencing and analysis of the human genome. Nature 409: 860-921.

Lee W, Jiang Z, Liu J, Haverty PM, Guan Y, Stinson J, Yue P, Zhang Y, Pant KP, Bhatt D, et al. 2010. The mutation spectrum revealed by paired genome sequences from a lung cancer patient. Nature 465: 473-477.

Li C, Fang R, Sun Y, Han X, Li F, Gao B, Iafrate AJ, Liu XY, Pao W, Chen H, et al. 2011. Spectrum of oncogenic driver mutations in lung adenocarcinomas from East Asian never smokers. PLOS ONE 6: e28204. doi: 10.1371/journal.pone.0028204.

Lipson D, Capelletti M, Yelensky R, Otto G, Parker A, Jarosz M, Curran JA, Balasubramanian S, Bloom T, Brennan KW, et al. 2012. Identification of new ALK and RET gene fusions from colorectal and lung cancer biopsies. Nat Med 18: 382-384.

Lovly CM, Pao W. 2012. Escaping ALK inhibition: Mechanisms of and strategies to overcome resistance. Sci Transl Med 4: 120ps2. doi: 10.1126/ scitranslmed.3003728.

Lynch TJ, Bell DW, Sordella R, Gurubhagavatula S, Okimoto RA, Brannigan BW, Harris PL, Haserlat SM, Supko JG, Haluska FG, et al. 2004. Activating mutations in the epidermal growth factor receptor underlying responsiveness of non-small-cell lung cancer to gefitinib. N Engl J Med 350: $2129-2139$.

Macconaill LE, Garraway LA. 2010. Clinical implications of the cancer genome. J Clin Oncol 28: 5219-5228.

Maemondo M, Inoue A, Kobayashi K, Sugawara S, Oizumi S, Isobe H, Gemma A, Harada M, Yoshizawa H, Kinoshita I, et al. 2010. Gefitinib or chemotherapy for non-small-cell lung cancer with mutated EGFR. $N$ Engl J Med 362: 2380-2388.

Malanga D, Scrima M, De Marco C, Fabiani F, De Rosa N, De Gisi S, Malara N, Savino R, Rocco G, Chiappetta G, et al. 2008. Activating E17K mutation in the gene encoding the protein kinase AKT1 in a subset of squamous cell carcinoma of the lung. Cell Cycle 7: 665-669.

Marks JL, Gong Y, Chitale D, Golas B, McLellan MD, Kasai Y, Ding L, Mardis ER, Wilson RK, Solit D, et al. 2008. Novel MEK1 mutation identified by mutational analysis of epidermal growth factor receptor signaling pathway genes in lung adenocarcinoma. Cancer Res 68: 5524-5528.

Mitsudomi T, Morita S, Yatabe Y, Negoro S, Okamoto I, Tsurutani J, Seto T, Satouchi M, Tada H, Hirashima T, et al. 2009. Gefitinib versus cisplatin plus docetaxel in patients with non-small-cell lung cancer harbouring mutations of the epidermal growth factor receptor (WJTOG3405): An open label, randomised phase 3 trial. Lancet Oncol 11: 121-128.

Mok TS, Wu YL, Thongprasert S, Yang CH, Chu DT, Saijo N, Sunpaweravong P, Han B, Margono B, Ichinose Y, et al. 2009. Gefitinib or carboplatinpaclitaxel in pulmonary adenocarcinoma. N Engl J Med 361: 947-957.

Neubauer MA, Hoverman JR, Kolodziej M, Reisman L, Gruschkus SK, Hoang S, Alva AA, McArthur M, Forsyth M, Rothermel T, et al. 2010. Cost effectiveness of evidence-based treatment guidelines for the treatment of non-small-cell lung cancer in the community setting. J Oncol Pract 6: 12-18

Paez JG, Janne PA, Lee JC, Tracy S, Greulich H, Gabriel S, Herman P, Kaye FJ, Lindeman N, Boggon TJ, et al. 2004. EGFR mutations in lung cancer: Correlation with clinical response to gefitinib therapy. Science 304: $1497-1500$.

Paik PK, Arcila ME, Fara M, Sima CS, Miller VA, Kris MG, Ladanyi M, Riely GJ. 2011. Clinical characteristics of patients with lung adenocarcinomas harboring BRAF mutations. J Clin Oncol 29: 2046-2051.

Pao W, Chmielecki J. 2010. Rational, biologically based treatment of EGFRmutant non-small-cell lung cancer. Nat Rev Cancer 10: 760-774.

Pao W, Hutchinson KE. 2012. Chipping away at the lung cancer genome. Nat Med 18: 349-351.

Pao W, Miller V, Zakowski M, Doherty J, Politi K, Sarkaria I, Singh B, Heelan R, Rusch V, Fulton L, et al. 2004. EGF receptor gene mutations are common in lung cancers from "never smokers" and are associated with sensitivity of tumors to gefitinib and erlotinib. Proc Natl Acad Sci 101: 13306-13311.

Pao W, Miller VA, Politi KA, Riely GJ, Somwar R, Zakowski MF, Kris MG, Varmus H. 2005a. Acquired resistance of lung adenocarcinomas to gefitinib or erlotinib is associated with a second mutation in the EGFR kinase domain. PLoS Med 2: e73. doi: 10.1371/journal.pmed.0020073.

Pao W, Wang TY, Riely GJ, Miller VA, Pan Q, Ladanyi M, Zakowski MF, Heelan RT, Kris MG, Varmus HE. 2005b. KRAS mutations and primary resistance of lung adenocarcinomas to gefitinib or erlotinib. PLoS Med 2: e17. doi: 10.1371/journal.pmed.0020017.

Pao W, Kris MG, Iafrate AJ, Ladanyi M, Janne PA, Wistuba II, Miake-Lye R, Herbst RS, Carbone DP, Johnson BE, et al. 2009. Integration of molecula profiling into the lung cancer clinic. Clin Cancer Res 15: 5317-5322.

Pao W, Iafrate AJ, Su Z. 2011. Genetically informed lung cancer medicine. J Pathol 223: 230-240.

Pratilas CA, Hanrahan AJ, Halilovic E, Persaud Y, Soh J, Chitale D, Shigematsu H, Yamamoto H, Sawai A, Janakiraman M, et al. 2008.
Genetic predictors of MEK dependence in non-small cell lung cancer. Cancer Res 68: 9375-9383.

Reck M, von Pawel J, Zatloukal P, Ramlau R, Gorbounova V, Hirsh V, Leighl N, Mezger J, Archer V, Moore N, et al. 2009. Phase III trial of cisplatin plus gemcitabine with either placebo or bevacizumab as first-line therapy for nonsquamous non-small-cell lung cancer: AVAil. J Clin Oncol 27: $1227-1234$.

Riely GJ, Kris MG, Rosenbaum D, Marks J, Li A, Chitale DA, Nafa K, Riedel ER, Hsu M, Pao W, et al. 2008. Frequency and distinctive spectrum of KRAS mutations in never smokers with lung adenocarcinoma. Clin Cancer Res 14: 5731-5734.

Riely GJ, Marks J, Pao W. 2009. KRAS mutations in non-small cell lung cancer. Proc Am Thorac Soc 6: 201-205.

Roychowdhury S, Iyer MK, Robinson DR, Lonigro RJ, Wu YM, Cao X, Kalyana-Sundaram S, Sam L, Balbin OA, Quist MJ, et al. 2011. Personalized oncology through integrative high-throughput sequencing: a pilot study. Sci Transl Med 3: doi: 10.1126/scitranslmed.3003261.

Sandler A, Gray R, Perry MC, Brahmer J, Schiller JH, Dowlati A, Lilenbaum R, Johnson DH. 2006. Paclitaxel-carboplatin alone or with bevacizumab for non-small-cell lung cancer. N Engl J Med 355: 2542-2550.

Schiller J, Harrington D, Belani C, Langer C, Sandler A, Krook J, Zhu J, Johnson D, Group TECO. 2002. Comparison of four chemotherapy regimens for advanced non-small-cell lung cancer. $N$ Engl J Med 346: 92-98.

Sequist LV, Heist RS, Shaw AT, Fidias P, Rosovsky R, Temel JS, Lennes IT, Digumarthy S, Waltman BA, Bast E, et al. 2011. Implementing multiplexed genotyping of non-small-cell lung cancers into routine clinical practice. Ann Oncol 22: 2616-2624.

Shaw AT, Yeap BY, Mino-Kenudson M, Digumarthy SR, Costa DB, Heist RS, Solomon B, Stubbs H, Admane S, McDermott U, et al. 2009. Clinical features and outcome of patients with non-small-cell lung cancer who harbor EML4-ALK. J Clin Oncol 27: 4247-4253.

Shedden K, Taylor JM, Enkemann SA, Tsao MS, Yeatman TJ, Gerald WL, Eschrich S, Jurisica I, Giordano TJ, Misek DE, et al. 2008. Gene expression-based survival prediction in lung adenocarcinoma: a multisite, blinded validation study. Nat Med 14: 822-827.

Siegel R, Ward E, Brawley O, Jemal A. 2011. Cancer statistics, 2011: The impact of eliminating socioeconomic and racial disparities on premature cancer deaths. CA Cancer I Clin 61: 212-236.

Soda M, Choi YL, Enomoto M, Takada S, Yamashita Y, Ishikawa S, Fujiwara S, Watanabe H, Kurashina K, Hatanaka H, et al. 2007. Identification of the transforming EML4-ALK fusion gene in non-small-cell lung cancer. Nature 448: 561-566.

Sonobe M, Manabe T, Wada H, Tanaka F. 2006. Lung adenocarcinoma harboring mutations in the ERBB2 kinase domain. J Mol Diagn 8: 351-356.

Su Z, Dias-Santagata D, Duke M, Hutchinson K, Lin YL, Borger DR, Chung CH, Massion PP, Vnencak-Jones CL, Iafrate AJ, et al. 2011. A platform for rapid detection of multiple oncogenic mutations with relevance to targeted therapy in non-small-cell lung cancer. J Mol Diagn 13: 74-84.

Sun Y, Ren Y, Fang Z, Li C, Fang R, Gao B, Han X, Tian W, Pao W, Chen H, et al. 2010. Lung adenocarcinoma from East Asian never-smokers is a disease largely defined by targetable oncogenic mutant kinases. J Clin Oncol 28: 4616-4620.

Takeuchi K, Soda M, Togashi Y, Suzuki R, Sakata S, Hatano S, Asaka R, Hamanaka W, Ninomiya H, Uehara H, et al. 2012. RET, ROS1 and ALK fusions in lung cancer. Nature Med 18: 378-381.

Tsao AS, Tang XM, Sabloff B, Xiao L, Shigematsu H, Roth J, Spitz M, Hong WK, Gazdar A, Wistuba I. 2006. Clinicopathologic characteristics of the EGFR gene mutation in non-small cell lung cancer. J Thorac Oncol 1: 231-239.

Venter JC, Adams MD, Myers EW, Li PW, Mural RJ, Sutton GG, Smith HO, Yandell M, Evans CA, Holt RA, et al. 2001. The sequence of the human genome. Science 291: 1304-1351.

Weinstein I. 2002. Cancer. Addiction to oncogenes-the Achilles heal of cancer. Science 297: 63-64.

Weir BA, Woo MS, Getz G, Perner S, Ding L, Beroukhim R, Lin WM, Province MA, Kraja A, Johnson LA, et al. 2007. Characterizing the cancer genome in lung adenocarcinoma. Nature 450: 893-898.

Weiss J, Sos ML, Seidel D, Peifer M, Zander T, Heuckmann JM, Ullrich RT, Menon R, Maier S, Soltermann A, et al. 2010. Frequent and focal FGFR1 amplification associates with therapeutically tractable FGFR1 dependency in squamous cell lung cancer. Sci Transl Med 2: 62ra93. doi: 10.1126/scitranslmed.3001451.

Wheat PF. 2001. History and development of antimicrobial susceptibility testing methodology. J Antimicrob Chemother 48 (Suppl 1): 1-4.

Yu SL, Chen HY, Chang GC, Chen CY, Chen HW, Singh S, Cheng CL, Yu CJ, Lee YC, Chen HS, et al. 2008. MicroRNA signature predicts survival and relapse in lung cancer. Cancer Cell 13: 48-57. 


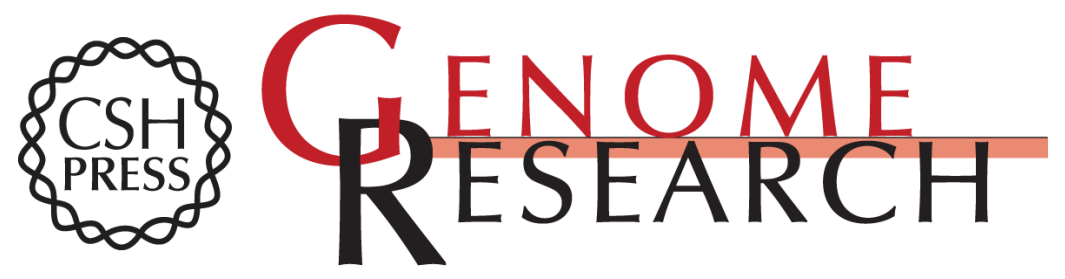

\section{Translating genomic information into clinical medicine: Lung cancer as a paradigm}

Mia A. Levy, Christine M. Lovly and William Pao

Genome Res. 2012 22: 2101-2108 originally published online September 27, 2012

Access the most recent version at doi:10.1101/gr.131128.111

Related Content The transcriptional landscape and mutational profile of lung adenocarcinoma Jeong-Sun Seo, Young Seok Ju, Won-Chul Lee, et al. Genome Res. November , 2012 22: 2109-2119 Translating cancer omics to improved outcomes

Emily A. Vucic, Kelsie L. Thu, Keith Robison, et al.

Genome Res. February , 2012 22: 188-195 Translational genomics: The challenge of developing cancer biomarkers

James D. Brooks

Genome Res. February , 2012 22: 183-187 An emerging toolkit for targeted

cancer therapies

Gordon B. Mills

Genome Res. February , 2012 22: 177-182 Genome-scale analysis of DNA

methylation in lung adenocarcinoma and integration with mRNA expression

Suhaida A. Selamat, Brian S. Chung, Luc Girard, et al.

Genome Res. July , 2012 22: 1197-1211 A transforming KIF5B and RET gene

fusion in lung adenocarcinoma revealed from whole-genome and transcriptome sequencing

Young Seok Ju, Won-Chul Lee, Jong-Yeon Shin, et al.

Genome Res. March , 2012 22: 436-445 Genetic basis of kidney cancer: Role of

genomics for the development of disease-based therapeutics

W. Marston Linehan

Genome Res. November , 2012 22: 2089-2100

References This article cites 67 articles, 25 of which can be accessed free at:

http://genome.cshlp.org/content/22/11/2101.full.html\#ref-list-1

Articles cited in:

http://genome.cshlp.org/content/22/11/2101.full.html\#related-urls

Open Access Freely available online through the Genome Research Open Access option.

\section{Affordable, Accurate Sequencing.}

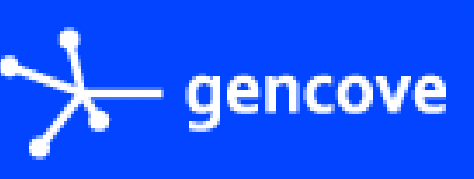

To subscribe to Genome Research go to:

https://genome.cshlp.org/subscriptions 
Creative This article is distributed exclusively by Cold Spring Harbor Laboratory Press for the Commons

License first six months after the full-issue publication date (see http://genome.cshlp.org/site/misc/terms.xhtml). After six months, it is available under a Creative Commons License (Attribution-NonCommercial 3.0 Unported License), as described at http://creativecommons.org/licenses/by-nc/3.0/.

Email Alerting Receive free email alerts when new articles cite this article - sign up in the box at the Service top right corner of the article or click here.

\section{Affordable, Accurate} Sequencing.

To subscribe to Genome Research go to: https://genome.cshlp.org/subscriptions 